\title{
Deskripsi Hasil Belajar Peserta Didik Pada Materi Yang Menerapkan Perhitungan Kimia Dengan Menggunakan Modul Berbasis Guided Inquiry
}

\section{Description of Student Learning Outcomes on Chemistry Materials that Implement Chemical Calculations Using Guided-Inquiry-Based Modules}

\author{
R A Rushiana ${ }^{1}$ and Iryani $^{1^{*}}$ \\ 1 Pendidikan Kimia, Universitas Negeri Padang, Jl. Prof. Dr. Hamka, Air Tawar Barat, \\ Padang Utara, Sumatera Barat, Indonesia. 25171 \\ *iryaniachmad62@gmail.com
}

\section{ARTICLE INFO \\ Received on: \\ 23 August 2020 \\ Revised till: \\ 10 November 2020}

Accepted on:

28 November 2020

Publisher version published on:

28 February 2021

\begin{abstract}
This study aims to describe the learning outcomes of students on materials of chemical calculations using guided inquiry-based modules. The materials for chemical calculations include chemical equilibrium, salt hydrolysis, and buffer solutions. The type of this research is literature research with a semi-systematic approach. The data source is in the form of secondary data from reputable and non-reputable scientific journals. The data were collected using the documentation method and analysed using content analysis techniques. Based on the results of the journal review that has been done, it can be concluded that the learning outcomes of students in learning using guided inquiry-based modules have increased significantly in materials of chemical calculations, namely chemical equilibrium and salt hydrolysis and buffer solutions. The use of guided inquiry-based modules can encourage students to be active during the learning process and there are models and key questions that can make help students to find concepts and the existence of practice questions at the application stage that can strengthen students' understanding.
\end{abstract}

\section{KEYWORDS}

Chemical Calculations, Guided Inquiry-Based Modules, Learning Outcomes

\begin{abstract}
ABSTRAK
Tujuan penelitian ini adalah untuk mendeskripsikan hasil belajar peserta didik pada materi yang menerapkan perhitungan kimia dengan menggunakan modul berbasis guided inquiry. Materi perhitungan kimia tersebut antara lain kesetimbangan kimia, hidrolisis garam, dan larutan buffer. Jenis penelitian yang diterapkan adalah penelitian kepustakaan dengan pendekatan semi-sistematis. Sumber data berupa data sekunder dari jurnal ilmiah bereputasi. Pengumpulan data dilakukan dengan menggunakan metode dokumentasi dan dianalisis dengan teknik analisis isi. Berdasarkan hasil tinjauan jurnal yang telah dilakukan dapat disimpulkan bahwa hasil belajar peserta didik pada pembelajaran menggunakan modul berbasis guided inquiry meningkat secara signifikan pada materi yang menerapkan perhitungan kimia yaitu pada materi kesetimbangan kimia dan hidrolisis garam dan larutan penyangga. Penggunaan modul berbasis guided inquiry dapat mendorong peserta didik untuk aktif selama proses pembelajaran dan adanya model dan pertanyaan kunci yang dapat membantu peserta didik dalam menemukan konsep serta adanya soal-soal latihan pada tahap aplikasi yang dapat memperkuat pemahaman peserta didik.
\end{abstract}

KATA KUNCI

Hasil Belajar, Modul Berbasis Guided Inquiry, Perhitungan Kimia 


\section{PENDAHULUAN}

Materi pembelajaran kimia umumnya melibatkan persamaan reaksi dan perhitungan kimia, seperti pada materi kesetimbangan kimia, hidrolisis garam dan larutan penyangga ${ }^{[1]}$. Peserta didik cenderung mengalami kesulitan pada pembelajaran yang terdapat reaksi kimia dan hitungan kimia. Hal ini disebabkan banyaknya aspek yang harus dikuasai peserta didik seperti konsep mol, menyetarakan reaksi dan menginterpretasikan permasalahan dari bahasa verbal menjadi persamaan matematis ${ }^{[2-4]}$.

Pada materi kimia yang berupa perhitungan matematika dan penggabungan konsep, diperlukan suatu pembelajaran yang dapat membantu keaktifan berpikir peserta didik sehingga peserta didik dapat membangun dan mengaitkan konsepkonsep yang dipelajari yaitu dengan menerapkan pendekatan saintifik yang merupakan landasan dalam menerapkan kurikulum $2013^{[5]}$.

Pada pembelajaran menggunakan kurikulum 2013, guru dituntut untuk dapat memilih bahan ajar dan model pembelajaran yang sesuai dengan materi pembelajaran. Salah satu model pembelajaran yang dapat digunakan dalam menerapkan kurikulum 2013 adalah Guided Inquiry Learning (GIL).

GIL merupakan pembelajaran yang dapat mengembangkan cara berpikir ilmiah peserta didik dalam memecahkan permasalahan dan memperoleh pengetahuan yang bersifat penyelidikan sehingga dapat memahami konsep-konsep sains ${ }^{[6]}$. Selain itu, proses GILdapat membuat peserta didikmendapatkan pengetahuan yang secara umum tersimpan dalam ingatan jangka panjang peserta didik ${ }^{[7]}$.

Kegiatan belajar GIL terdiri dari tahap orientasi, tahap eksplorasi, tahap pembentukan konsep, tahap aplikasi dan tahap penutup ${ }^{[8]}$. GIL dapat meningkatkan hasil belajar peserta didik. Hal ini dikarenakan GIL membuat peserta didik lebih terlibat aktif dan bekerja sama dalam berdiskusi[9-10].

Penerapan model GIL dapat menggunakan modul pembelajaran. Modul yang dapat digunakan untuk menerapkan model GIL adalah modul berbasis guided inquiry yang di dalamnya mencakup tahapan-tahapan dari model pembelajaran guided inquiry. Penggunaan modul berbasis guided inquiry dapat mendorong peserta didik untuk aktif menganalisis, memecahkan permasalahan berdasarkan fakta-fakta yang ditemukan sehingga diperoleh pemahaman konseptual ${ }^{[11]}$. Bahan ajar berupa modul yang disusun berdasarkan model GIL dapat meningkatkan hasil belajar peserta didik ${ }^{[2-14]}$.

Berdasarkan uraian di atas, tujuan dari penelitian ini untuk mendeskripsikan hasil belajar peserta didik pada materi yang menerapkan perhitungan kimia dengan menggunakan modul berbasis guided inquiry. Materi perhitungan kimia dalam penelitian ini yaitu materi kesetimbangan kimia, hidrolisis garam dan larutan penyangga. Ketiga materi tersebut memiliki persamaan karakteristik yaitu abstrak dan algoritmik ${ }^{[15-17]}$.

Penelitian ini dapat menjadi sumber informasi bagi guru mengenai hasil belajar peserta didik dengan menggunakan modul berbasis guided inquiry pada pembelajaran kimia khususnya pada materi kimia yang terdapat perhitungan kimia. Penelitian ini diharapkan pula menjadi bahan pertimbangan dalam menggunakan modul berbasis guided inquiry dan sebagai referensi yang digunakan untuk penelitian selanjutnya.

\section{METODE}

Jenis penelitian yang diterapkan adalah penelitian kepustakaan yang merupakan penelitian yang dilakukan dengan cara menganalisis data yang dikumpulkan dari literatur-literatur ${ }^{[18]}$. Penelitian kepustakaan ini dilakukan dengan menerapkan pendekatan semi-sistematis. Penggunaan pendekatan semi-sistematis pada penelitian ini bertujuan untuk mengidentifikasi dan memahami penelitian yang berpotensi relevan dan memiliki keterkaitan dengan topik yang diteliti ${ }^{[19]}$.

Data sekunder merupakan sumber data yang diterapkan pada penelitian ini. Data tersebut dikumpulkan dengan menerapkan metode dokumentasi. Sumber data sekunder pada penelitian ini berupa jurnal bereputasi dan didukung dengan jurnal yang belum bereputasi. Jurnal-jurnal tersebut dipilih dari situs database jurnal diantaranya https:// www.tandfonline.com/, https://www.elsevier.com/enxs, https://iopscience.iop.org/, https://onlinelibrary. wiley.com/dan https://scholar.google.com/.

Data sekunder yang telah didapatkan dianalisis menggunakan teknik analisis isi. Dalam analisis ini dilakukan proses memilih, membandingkan, menggabungkan dan memilah atau menganalisis berbagai sumber sehingga didapatkan data yang sesuai atau relevan.

Penelitian ini dilakukan dengan tahapan sebagai berikut: 1) Mendesain review. Pada tahap desain review dilakukan pemilihan topik, penentuan tujuan dan rumusan masalah yang akan dibahas dalam review serta menentukan kriteria artikel yang digunakan yaitu artikel yang diterbitkan sejak tahun 2000; 2) Melakukan review. Tahap ini dilakukan dengan cara melakukan tinjauan secara bertahap dengan membaca abstrak pada artikel yang sesuai dengan topik penelitian. Jika abstrak telah sesuai dengan topik penelitian dilanjutkan dengan membaca isi artikel; 3) Analisis. Analisis artikel dilakukan sesuai dengan tujuan dan rumusan masalah penelitian. Analisis artikel dilakukan untuk mendapatkan data informasi deskriptif seperti pengarang, tahun terbit, topik, jenis penelitian dan hasil temuan; 4) Menulis review. Penulisan review dilakukan sesuai dengan topik penelitian ${ }^{[19]}$.

\section{HASIL DAN DISKUSI}

\subsection{Hasil Penelitian}

Hasil tinjauan diperoleh dari delapan jurnal bereputasi dan tujuh jurnal yang belum bereputasi. Jurnal yang berkaitan dengan penggunaan modul pembelajaran terdiri dari empat jurnal, kemudian dari keempat jurnal ini didapatkan hasil penelitian 
dari proses pembelajaran menggunakan modul. Jurnal yang berkaitan dengan model guided inquiry terdiri dari tujuh jurnal, lalu dari ketujuh jurnal tersebut diambil tahap-tahap belajar GIL dan hasil research mengenai pembelajaran guided inquiry. Jurnal yang berkaitan dengan hasil belajar peserta didik pada pembelajaran menggunakan modul guided inquiry terdiri dari empat jurnal. Hasil uji hipotesis pada materi kesetimbangan kimia terangkum pada Tabel 1.

Tabel 1. Hasil Uji Hipotesis Kelas Sampel ${ }^{[20]}$.

\begin{tabular}{c|c|c|c|c} 
Kelas & $\mathbf{S}$ & $\mathbf{S}^{2}$ & $\mathbf{t}_{\text {hitung }}$ & $\mathbf{t}_{\text {tabel }}$ \\
\hline Eksperimen & 10,518 & 110,629 & \multirow{2}{*}{5,72} & 1,66 \\
\hline Kontrol & 12,24 & 149,92 & &
\end{tabular}

Hasil uji hipotesis menunjukkan bahwa hipotesis penelitian diterima. Hal ini menunjukkan bahwa hasil belajar peserta didik meningkat secara signifikan melalui pembelajaran menggunakan modul berbasis guided inquiry. Hasil uji Wilcoxon pada materi hidrolisis garam dapat diketahui pada Tabel 2.

Tabel 2. Hasil Uji Wilcoxon ${ }^{[21]}$.

\begin{tabular}{c|c|c} 
Sekolah & $\begin{array}{c}\text { Nilai } \\
\text { Signifikansi }\end{array}$ & $\boldsymbol{\alpha}$ \\
\hline SMAN 1 Pekalongan & 0,000 & 0,05 \\
\hline SMAN 2 Sekampung & 0,000 & 0,05 \\
\hline MA Ma'arif 5 Sekampung & 0,000 & 0,05
\end{tabular}

Hasil uji Wilcoxon menunjukkan bahwa hasil belajar peserta didik meningkat secara signifikan melalui pembelajaran menggunakan modul berbasis guided inquiry. Nilai rata-rata $N$-Gain peserta didik pada materi larutan penyangga dapat diketahui pada Tabel 3.

Tabel 3. Nilai Rerata $N$-Gain ${ }^{[22]}$.

\begin{tabular}{c|c|c|l}
$\overline{\mathbf{X}}$ pretes & $\overline{\mathbf{X}}$ postes & Rerata $\boldsymbol{N}$-Gain & Kategori \\
\hline 18,8 & 84,6 & 0,7 & Tinggi
\end{tabular}

Nilai rerata $N$-Gain tersebut menunjukkan bahwa penggunaan modul berbasis guided inquiry efektif dalam meningkatkan hasil belajar peserta didik pada materi larutan penyangga.

\subsection{Pembahasan}

\subsubsection{Penggunaan Modul Pembelajaran}

Hasil tinjauan dari beberapa jurnal didapatkan bahwa modul merupakan alat atau sarana pembelajaran yang berisi materi pembelajaran, metode, tujuan pembelajaran dan soal evaluasi yang disusun secara sistematis dan menarik untuk mencapai kompetensi yang diharapkan ${ }^{[23]}$. Penggunaan modul pembelajaran dapat meningkatkan, keterampilan pemecahan masalah, berpikir kritis dan kreatif, keterampilan proses sains serta meningkatkan motivasi peserta didik sehingga secara tidak langsung dapat meningkatkan hasil belajar peserta didik ${ }^{[24]}$. Hal ini dikarenakan adanya lembar aktivitas dan lembar kerja yang dapat memudahkan peserta didik dalam menemukan konsep dan menerapkan konsep pada materi yang sedang dipelajari ${ }^{[25]}$.

\subsubsection{Model Guided Inquiry Learning (GIL)}

Hasil tinjauan dari beberapa jurnal terdapat dua sumber mengenai tahap GIL. Menurut pendapat yang pertama yaitu orientasi, eksplorasi, pembentukan konsep, aplikasi dan penutup ${ }^{[8]}$. Tahapan GIL lainnya terdiri dari tahap inisiasi, seleksi, eksplorasi, formulasi, koleksi dan presentasi ${ }^{[26]}$. Dari kedua tahapan GIL yang dikemukakan tersebut, diambil kesamaan dan kesimpulan yaitu tahapan GIL terdiri dari orientasi, eksplorasi, pembentukan konsep, aplikasi dan kesimpulan.

Berdasarkan hasil tinjauan mengenai GIL menyatakan bahwa hasil belajar peserta didik lebih tinggi dengan menerapkan GIL ${ }^{[27-29]}$. Hal ini dikarenakan beberapa faktor yaitu pada proses pembelajaran adanya umpan balik dan tanggapan yang diberikan guru kepada peserta didik terhadap masalah yang ditemukan. Hal ini dilakukan untuk memeriksa pemahaman peserta $\operatorname{didik}^{[27]}$.

Proses pembelajaran menggunakan model GIL dilakukan secara berkelompok. Pembelajaran secara berkelompok akan meningkatkan pemahaman peserta didik karena adanya diskusi kelompok. Diskusi kelompok yang dilakukan akan meningkatkan berpikir kritis, keterampilan bekerja sama, dan membuat peserta didik belajar mempertahankan argumen. Selain itu diskusi kelompok memberikan peluang bagi peserta didik untuk menyampaikan ide mereka sehingga setiap kelompok dapat memecahkan masalah bersama $^{[29]}$. Pembelajaran secara berkelompok juga dapat melatih peserta didik dalam mengatur waktu $^{[27]}$. Proses GIL dapat membuat peserta didik mendapatkan pengetahuan yang tersimpan dalam ingatan jangka panjang peserta didik ${ }^{[7]}$.

\subsubsection{Deskripsi Hasil Belajar Peserta Didik dengan Menggunakan Modul Berbasis Guided Inquiry}

Pada Materi yang Menerapkan Perhitungan Kimia

Berdasarkan hasil tinjauan mengenai model GIL dan penggunaan modul pembelajaran dapat disimpulkan bahwa modul pembelajaran apabila mengikuti tahapan GIL akan menunjukkan hasil yang baik dalam proses pembelajaran maupun hasil belajar peserta didik. Hal ini didukung dari hasil tinjauan beberapa penelitian.

Penelitian pertama mengenai efektivitas modul berbasis guided inquiry pada materi kesetimbangan kimia dapat diketahui bahwa ada perbedaan hasil belajar peserta didik pada kedua kelas sampel. Hal ini dapat diketahui pada hasil uji hipotesis. Dari hasil tersebut didapatkan bahwa hasil belajar di kelas eksperimen secara signifikan lebih tinggi daripada kelas kontrol ${ }^{[20]}$. Hal ini dapat diketahui dari hasil uji hipotesis seperti yang tercantum pada Tabel 1.

Penelitian kedua menyatakan bahwa hasil belajar peserta didik meningkat secara signifikan dengan pembelajaran menggunakan modul berbasis guided 
inquiry pada materi hidrolisis garam. Hal ini dapat diketahui dari hasil uji Wilcoxon pada Tabel 2. Pada tabel tersebut dapat diketahui bahwa Ho ditolak yang berarti ada perbedaan yang signifikan antara nilai tes sebelum hidrolisis garam pembelajaran dan sesudah pembelajaran hidrolisis garam pada ketiga sekolah ${ }^{[21]}$.

Pada penelitian ketiga, dapat diketahui bahwa hasil belajar peserta didik meningkat dengan pembelajaran menggunakan modul berbasis guided inquiry pada materi larutan penyangga. Hal ini dapat diketahui dari nilai rata-rata $\mathrm{N}$-Gain seperti yang tercantum pada Tabel 3. Dari hasil tersebut dapat diketahui bahwa modul berbasis guided inquiry pada materi larutan penyangga efektif dalam meningkatkan hasil belajar peserta didik ${ }^{[22]}$.

Penggunaan modul berbasis guided inquiry telah terbukti memberikan hasil yang baik terhadap hasil belajar peserta didik pada materi kesetimbangan kimia, hidrolisis garam dan larutan penyangga. Hal ini dibuktikan dengan adanya peningkatan hasil belajar peserta didik secara signifikan. Peningkatan hasil belajar tersebut dikarenakan penggunaan modul berbasis guided inquiry memberikan bimbingan kepada peserta didik dalam menemukan konsep melalui model, pertanyaan kunci, latihan yang terdapat di dalam modul. Penggunaan modul berbasis guided inquiry membuat peserta didik lebih aktif dan memiliki kemampuan berpikir kritis dalam proses pembelajaran karena peserta didik dituntut untuk menyelesaikan masalah sendiri dengan bantuan pertanyaan kunci ${ }^{[20]}$.

Modul guided inquiry merupakan modul yang disusun berdasarkan tahapan GIL. Kegiatan pertama pada pembelajaran menggunakan modul tersebut yaitu guru mempersiapkan peserta didik untuk belajar dengan cara memberikan apersepsi dan motivasi untuk menciptakan minat dan rasa ingin tahu peserta didik.

Kegiatan yang kedua pada pembelajaran menggunakan modul berbasis guided inquiry yaitu tahap eksplorasi dilakukan dengan pengamatan model yang terdapat di dalam modul atau dapat berupa pengamatan pada eksperimen yang dilakukan. Tahap eksplorasi dilakukan secara berkelompok sehingga peserta didik dapat bertukar pendapat. Kegiatan yang ketiga adalah pembentukan konsep, tahap ini berhubungan dengan tahap eksplorasi. Pada tahap pembentukan konsep, peserta didik menghubungkan fakta-fakta dari hasil eksperimen dengan model dan pertanyaan kritis yang terdapat dalam modul. Pertanyaan kritis merupakan inti dari GIL karena melalui pertanyaan kritis peserta didik aktif bekerja untuk mempelajari konten baru.

Kegiatan yang keempat adalah aplikasi. Pada tahap ini peserta didik mengerjakan latihan yang terdapat di dalam modul. Pengerjaan latihan bertujuan untuk memperkuat dan memperluas pemahaman yang telah didapatkan serta mengembangkan kepercayaan diri peserta didik. Kegiatan yang terakhir adalah penutup. Pada tahap ini peserta didik membuat dan menyampaikan kesimpulan dengan menggabungkan beberapa pengetahuan yang telah mereka temukan. Hal ini dilakukan untuk meningkatkan kemampuan peserta didik dalam menilai kinerja dirinya ${ }^{[2,22,30]}$.

\section{SIMPULAN}

Berdasarkan tinjauan dari beberapa penelitian dapat disimpulkan bahwa hasil belajar peserta didik yang menggunakan modul berbasis guided inquiry meningkat secara signifikan pada materi kesetimbangan kimia, hidrolisis garam, dan larutan penyangga. Hal ini dikarenakan penggunaan modul berbasis guided inquiry dapat membuat peserta didik lebih aktif selama pembelajaran dan adanya model dan pertanyaan kunci yang membantu peserta didik dalam menemukan konsep serta soal-soal latihan pada tahap aplikasi yang dapat memperkuat pemahaman peserta didik.

\section{REFERENSI}

1. Rijani EW. Implementasi Metode Latihan Berjenjang Untuk Meningkatkan Kemampuan Siswa Menyelesaikan Soal-Soal Hitungan Pada Materi Stoikiometri Di SMA. E-Jurnal Dinas Pendidikan Kota Surabaya. 2011;1:1-6.

2. Sunyono, Maryatun S, Surwati S. Optimalisasi Pembelajaran Kimia Kelas XI Semester 1 SMA Swadhipa Natar Melalui Penerapan Metode Eksperimen Menggunakan Bahan-Bahan Yang Ada Di Lingkungan. Lampung; 2005.

3. Zakiyah, Ibnu S, Subandi. Analisis Dampak Kesulitan Siswa pada Materi Stoikiometri Terhadap Hasil Belajar Termokimia. EduChemia (Jurnal Kimia dan Pendidikan). 2018;3(1):119-34.

4. Kimberlin S, Yezierski E. Effectiveness of Inquiry-Based Lessons Using Particulate Level Models to Develop High School Students' Understanding of Conceptual Stoichiometry. Journal of Chemical Education. 2016;93(6):1002-9.

5. Tri Wasonowati RR, Redjeki T, Ariani S. Penerapan Model Problem Based Learning (PBL) Pada Pembelajaran Hukum - Hukum Dasar Kimia Ditinjau Dari Aktivitas Dan Hasil Belajar Siswa Kelas X IPA SMA Negeri 2 Surakarta Tahun Pelajaran 2013/2014. Jurnal Pendidikan Kimia. 2014;3(3):66-75.

6. Amilasari A dan S. Peningkatan Kecakapan Akademik Siswa SMA dalam Pembelajaran Fisika Melalui Penerapan Inquiry Terbimbing. Jurnal Pengajaran MIPA FPMIPA UPI. 2008;12(2).

7. Blanchard MR, Southerland SA, Osborne JW, Sampson VD, Annetta LA, Granger EM. Is inquiry Possible in Light of Accountability?: A Quantitative Comparison of The Relative Effectiveness of Guided Inquiry and Verification Laboratory Instruction. Science Education. 2010;94(4):577-616.

8. Hanson D. Designing Process-Oriented Guided-Inquiry Activities. 2005;(1995):2-5. 
9. Wahyudi LE, Supardi ZAI. Penerapan Model Pembelajaran Inkuiri Terbimbing Pada Pokok Bahasan Kalor Untuk Melatihkan Keterampilan Proses Sains. Jurnal Nalar Pendidikan. 2017;02(02):62-5.

10. Vlassi M, Karaliota A. The Comparison between Guided Inquiry and Traditional Teaching Method. A Case Study for the Teaching of the Structure of Matter to 8th Grade Greek Students. Procedia - Social and Behavioral Sciences. 2013;93:494-7.

11. Rusche, S. N \& Jason K. "You Have to Absorb Yourself in it”: Using Inquiry and Reflection to Promote Student Learning and Self-knowledge. American Sociological Association. 2011;39(4).

12. Andromeda, Ellizar, Iryani, Yerimadesi, Rahmah F. The Effectiveness of Guided Inquiry Based Colloid System Modules Integrated Experiments on Science Process Skills and Student Learning Outcomes. Journal of Physics: Conference Series. 2019;1317(1).

13. Hidayat T, Andromeda. Efektivitas Penggunaan Modul Laju Reaksi Berbasis Inkuiri Terbimbing Terintegrasi Eksperimen Untuk Meningkatkan Hasil Belajar Siswa. Journal of Residu. 2019;3(13):69-76.

14. Pratiwi I, D RE, Silaban R, Suyanti RD. Pengembangan Modul Berbasis Inkuiri Terbimbing Pada Materi Hukum Dasar Kimia Di Sekolah Menengah Atas. Talenta Conference Series: Science and Technology (ST). 2019;2(1):187-93.

15. Pahriah. Pengaruh Pendekatan Inkuiri Terbimbing dipadu dengan Diagram Alir terhadap Prestasi Belajar Siswa SMA. Prisma Sains : Jurnal Pengkajian Ilmu dan Pembelajaran Matematika dan IPA IKIP Mataram. 2015;3(2):59.

16. Awaliyah N. Keefektifan DSLM Untuk Meningkatkan Pemahaman Konsep Mahasiswa Terhadap Materi Hidrolisis Garam. In: Seminar Nasional Pendidikan Biologi dan Saintek II. 2017. hal. 557-70.

17. Maratusholihah, N., Rahayu, Sri., Fajaroh F. Analisis Miskonsepsi Siswa SMA Pada Materi Hidrolisis Garam dan Larutan Penyangga. Jurnal Pendidikan. 2017;2(7).

18. Sukardi. Metodologi Penelitian Pendidikan: Kompetensi dan Praktiknya. Jakarta: Bumi Aksara; 2008.

19. Snyder H. Literature review as a research methodology: An overview and guidelines. Journal of Business Research. 2019;104(July):333-9.

20. Andromeda, Iryani, Ellizar, Yerimadesi, Sevira WP. Effectiveness of Chemical Equilibrium Module Based Guided Inquiry Integrated Experiments on Science Process Skills High School Students. Journal of Physics: Conference Series. 2019;1185(1).

21. Sudigdo A dan Perdana R. The Development of Chemistry Teaching Module SMA/MA Based Guided Inquiry to Improve Students' Achievement on Hydrolisis Salt Content. Journal of Xi'an University of Architecture \& Technology. 2020;XII(V):1300-9.

22. Iryani, Fitriza Z, Iswendi, Bayharti, Yunisa W, Ifelicia P. Development of Buffer Solution Module Based on Guided Inquiry and Multiple Representations. Journal of Physics: Conference Series. 2019;1317(1).

23. Depdiknas. Penulisan Modul. 2008.

24. Puspitasari AD. Penerapan Media Pembelajaran Fisika Menggunakan Modul Cetak dan Modul Elektronik pada Siswa SMA. Jurnal Pendidikan Fisika. 2019;7(1):17-25.

25. Bayharti, Azumar OR, Andromeda, Yerimadesi. Effectiveness of Redox and Electrochemical Cell Module Based Guided Discovery Learning on Critical Thinking Skills and Student Learning Outcomes of High School. Journal of Physics: Conference Series. 2019;1317(1).

26. Kuhlthau CC. Guided Inquiry : School Libraries in the 21 st Century. School Libraries Worldwide. 2010;16(1):17-27.

27. Douglas EP, Chiu C-C. Process-oriented Guided Inquiry Learning in Engineering. Procedia - Social and Behavioral Sciences. 2012;56(Ictlhe):253-7.

28. Koksal EA, Berberoglu G. The Effect of Guided-Inquiry Instruction on 6th Grade Turkish Students' Achievement, Science Process Skills, and Attitudes Toward Science. International Journal of Science Education. 2014;36(1):66-78.

29. Barthlow MJ, Watson SB. The Effectiveness of Process-Oriented Guided Inquiry Learning to Reduce Alternative Conceptions in Secondary Chemistry. School Science and Mathematics. 2014;114(5):246-55.

30. Devi, Arpiana dan Mukhamad N. Efektivitas Penggunaan Model Pembelajaran POGIL untik Menurunkan Miskonsepsi Siswa Kelas XI MIPA 5 Di SMA Negeri 4 Samarinda Pada Pokok Bahasan Hidrolisis Garam. Jurnal Zarah. 2020;8(1):38-43. 